\title{
Evaluation and Selection of Potential Biomass Sources of North-East India towards Sustainable Bioethanol Production
}

\author{
Grihalakshmi D. Nongthombam ${ }^{1 *}$, Rajendra K. Labala1, Sudripta Das ${ }^{1}$, \\ Pratap J. Handique ${ }^{2}$ and Narayan C. Talukdar ${ }^{3 *}$
}

${ }^{1}$ Institute of Bioresources and Sustainable Development (IBSD), Imphal, India, ${ }^{2}$ Department of Biotechnology, Gauhati University, Guwahati, India, ${ }^{3}$ Division of Life Sciences, Institute of Advanced Study in Science and Technology, Guwahati, India

OPEN ACCESS

Edited by:

JunYong Zhu,

University of Wisconsin-Madison,

United States

Reviewed by:

Yong Xu,

Nanjing Forestry University, China

Diwakar Rana,

DuPont, United States

Tae Hyun Kim,

Hanyang University, South Korea

${ }^{*}$ Correspondence:

Grihalakshmi D. Nongthombam

griha789@gmail.com;

Narayan C. Talukdar nctalukdar@yahoo.com

Specialty section:

This article was submitted to Bioenergy and Biofuels, a section of the journal Frontiers in Energy Research

Received: 26 March 2017 Accepted: 20 June 2017

Published: 11 July 2017

Citation:

Nongthombam GD, Labala RK,

Das S, Handique PJ and Talukdar NC

(2017) Evaluation and Selection of

Potential Biomass Sources of

North-East India towards Sustainable

Bioethanol Production.

Front. Energy Res. 5:16.

doi: 10.3389/fenrg.2017.00016
Vegetation biomass production in North-East India within Indo-Burma biodiversity hotspot is luxuriant and available from April to October to consider their potential for bioethanol production. Potential of six lignocellulosic biomass (LCB) sources; namely, sugarcane bagasse (BG), cassava aerial parts (CS), ficus fruits (Ficus cunia) (FF), "phumdi" (floating biomass), rice straw (RS), and sawdust were investigated for bioethanol production using standard techniques. Morphological and chemical changes were evaluated by Scanning electron microscopy and Fourier transform infrared spectroscopy and quantity of sugars and inhibitors in LCB were determined by High performance liquid chromatography. Hydrothermally treated BG, CS, and FF released 954.54, 1,354.33, and $1,347.94 \mathrm{mg} / \mathrm{L}$ glucose and $779.31,612.27$, and 1,570.11 mg/L of xylose, respectively. Inhibitors produced due to effect of hydrothermal pretreatment ranged from 42.8 to $145.78 \mathrm{mg} / \mathrm{L}$ acetic acid, below detection level (BDL) to $17.7 \mu \mathrm{g} / \mathrm{L} 5$-hydroxymethylfurfural, and BDL to $56.78 \mu \mathrm{g} / \mathrm{L}$ furfural. The saccharification efficiency of hydrothermally treated LCB (1.35-28.64\%) was significantly higher compared with their native counterparts (0.81-17.97\%). Consolidated bioprocessing of the LCB using MTCC 1755 (Fusarium oxysporum) resulted in maximum ethanol concentration of $0.85 \mathrm{~g} / \mathrm{L}$ and corresponded to $42 \mathrm{mg}$ ethanol per gram of hydrothermally treated BG in $120 \mathrm{~h}$ followed by $0.83 \mathrm{~g} / \mathrm{L}$ corresponding to $41.5 \mathrm{mg} / \mathrm{g}$ of untreated CS in $144 \mathrm{~h}$. These ethanol concentrations corresponded to 23.43 and $21.54 \%$ of theoretical ethanol yield, respectively. LCB of CS and FF emerged as a suitable material to be subjected to test for enhanced ethanol production in future experiments through efficient fermentative microbial strains, appropriate enzyme loadings, and standardization of other fermentation parameters.

Keywords: bioethanol, lignocellulosic biomass, pretreatment, sugarcane bagasse, enzymatic saccharification, consolidated bioprocessing

\section{INTRODUCTION}

Over the last few decades, lignocellulosic biomass (LCB) owing to its abundance in the terrestrial biosphere, has emerged as the most significant and attractive source for production of next-generation cellulosic bioethanol in sustainable and eco-friendly manner. In fact, the cellulose and hemicellulose constituents of LCB are converted to bioethanol through microbial fermentation (Chen et al., 2011; Sigurbjornsdottir and Orlygsson, 2012; Zuber and Dwivedi, 2013). However, the quality and structural 
complexity of LCB vary with plant-type and agronomic conditions (Liu et al., 2009; Zhang et al., 2012) and consequently determine the processing strategies such as thermochemical pretreatments with dilute acid, ammonia, or hot water (Laser et al., 2002; Kim and Lee, 2006; Lau et al., 2010; Da Cruz et al., 2012; Guo et al., 2013) required to yield sugars upon enzymatic hydrolysis and subsequently ethanol production by fermentation process (Larsen et al., 2012). Assessment of the chemical compositions and structural characterization of LCB is, therefore, a prerequisite for the optimization of approaches in cellulosic bioethanol production (Liu et al., 2009). In other words, such assessment provides data for judging the suitability of a particular plant biomass either in its native or pretreated form as feedstock and also standardizing the bioethanol production process.

In view of the urgent need for reduction in $\mathrm{CO}_{2}$ emission and concerns over hike in fossil fuel prices, demand for biobased bioethanol is increasing and global targets are set to reach 43 billion liters by 2025 (La Rovere et al., 2011). To meet this target, it is imperative to explore all available diversity and quantum of plant biomass spread across different regions of the world. A large quantity of LCB of certain vegetation are produced under the favorable tropical humid climate of North-East region of India (NERI) within the Indo-Burma biodiversity hotspot and available almost throughout the year ensuring continuous biomass supply for operating bioethanol production factory. LCB such as rice straw (RS), wheat bran, wheat straw, sawdust (SD), rice husk, corn straw, sugarcane bagasse (BG), cassava, and water hyacinth have been reported as suitable sources for bioethanol production (Martín et al., 2007; Binod et al., 2010). Sugarcane BG has been reported to be one of the most extensively studied biomass for bioethanol production (Lima et al., 2014). However, in NERI, sugarcane is not grown extensively but rather the aerial biomass of cassava (Manihot esculenta), fruits of non-edible fig (Ficus cunia) trees (bear four to five times within a year producing a large quantity of fruit biomass), RS (available in two seasons July-December and April-June), SD (from the forest timbers), and floating biomass [phumdi $(\mathrm{PH})]$ of Loktak lake $(2,00,000$ tonnes DM from the $100 \mathrm{~km}^{2}$ freshwater area per year) provide a huge prospect for biomass-based biofuel production. There is no information available on chemical compositions and suitable processing strategy for efficient conversion of these locally available LCB to bioethanol. Generally, methods of pretreatments of LCB and bioethanol yield vary depending upon the type of LCB and saccharification conditions employed (Liyakathali, 2014) and therefore, it was required to evaluate the six potential feedstocks to yield sugar for fermentation through hydrothermal and sodium hydroxide pretreatments. Lima et al. (2014) recently reported suitability of sodium hydroxide for pretreatment of lignocellulosic feedstocks. Overall, the objective of this research was to determine (i) compositions, inhibitors concentration, and the modifications in the structure of biomass after pretreatments using different analytical tools: scanning electron microscopy (SEM), Fourier transform infrared (FTIR), high performance liquid chromatography (HPLC), and Principal component analysis (PCA) and (ii) suitability of these six biomasses for bioethanol production in preliminary screening through consolidated bioprocessing (CBP) without supplementation of extraneous enzymes.

\section{MATERIALS AND METHODS}

\section{Production, Collection, and Preparation of the Five Feedstocks}

Plant biomass used in this study was either grown in the Institute of Bioresources and Sustainable Development (IBSD) campus park or collected from Imphal valley. The fruits of 11- year old F. cunia plant were harvested five times in 2012 during which the yield per fruiting ranged from 97 to $256 \mathrm{~kg} /$ plant. The fruits were dried in a greenhouse until the moisture content reached $8-10 \%$ and used for their composition analysis. The aboveground biomass was harvested from 65 days old cassava grown at Hararou Bioresources Park of IBSD, Imphal. Four to five kilograms biomass was obtained per hectare. The RS was collected from the Imphal valley, whose cumulative annual yield has been estimated at 2.5 tonnes per hectare (total rice cultivated area: 19,500 ha) calculated at $6-12 \%$ moisture content. $\mathrm{PH}$ were collected from the premises of Loktak Lake. $\mathrm{PH}$, the floating biomass, is a heterogeneous aggregate of soil, vegetation, and organic matters at various phases of decomposition that has transformed into a solid form used in the present investigation. Sugarcane BG was collected from a local vendor while SD was obtained from a saw mill factory. All the collected biomass samples were air dried in a greenhouse maintained at $50^{\circ} \mathrm{C}$ and subsequently chopped into 1-2 cm small pieces and ground in a mixer. The grounded substrates were passed through a sieve ( $1 \mathrm{~mm}$ pore size) and stored in airtight containers at room temperature until further treatments.

\section{Estimation of Soluble Extractives, Cellulose, Hemicelluloses, and Lignin Content in the Native LCB}

The biomasses were analyzed for soluble extractives, cellulose, hemicelluloses, and lignin contents. Soluble extractives were determined using the protocol as described by Lima et al. (2014). Cellulose was determined using the protocol with slight modifications (Updegraff, 1969). A gram of biomass sample was mixed with $50 \mathrm{~mL}$ of acetic/nitric reagent. The samples were transferred to a water bath maintained at $100^{\circ} \mathrm{C}$ for $1 \mathrm{~h}$; then followed by centrifugation at 4,000 rpm for $10 \mathrm{~min}$. The supernatant was discarded and the residue left was washed with sterile distilled water (SDW) and then dissolved in $100 \mathrm{~mL}$ of sulfuric acid (0.75: 0.25 volume fraction of SDW). The solution obtained was diluted with SDW to $100 \times$ and then, the glucose content was estimated using o-Toluidine reagent (Goodwin, 1970).

For determination of lignin and hemicelluloses content, $0.5 \mathrm{~g}$ of biomass was mixed with $30 \mathrm{~mL}$ of $0.5 \mathrm{~mol} / \mathrm{L} \mathrm{NaOH}$ and autoclaved at $121^{\circ} \mathrm{C}$ for $60 \mathrm{~min}$. The mixture obtained was incubated at room temperature for $60 \mathrm{~h}$ with intermittent shaking followed by centrifugation at $4,000 \mathrm{~g}$ for $10 \mathrm{~min}$. The neutralization of the supernatant to $\mathrm{pH} 7$ was made using concentrated $\mathrm{H}_{2} \mathrm{SO}_{4}$. Ten times diluted sample was prepared from the supernatant with SDW to estimate the total xylose using o-Toluidine reagent, as described by Goodwin (1970). For lignin estimation, five times diluted from the supernatant with SDW was estimated in terms of total phenol content using Folin Ciocalteu reagent following the protocol described by Singleton and Rossi (1965). 


\section{Pretreatment of the Lignocellulosic Substrates}

The selected feedstocks were hydrothermally pretreated with some modifications (Da Cruz et al., 2012). Suspension of $10 \mathrm{~g}$ biomass in $100 \mathrm{~mL}$ of distilled water was autoclaved at $121^{\circ} \mathrm{C}$ for $30 \mathrm{~min}$. The solid fractions were separated by vacuum filtration employing $0.45 \mu \mathrm{m}$ pore size glass fiber filter. The solid residues were washed with distilled water of volume equal to 20 times the mass of solids and dried at room temperature. Simultaneously, all the types of biomasses were pretreated with $0.25 \mathrm{M}$ sodium hydroxide at $130^{\circ} \mathrm{C}$ for $40 \mathrm{~min}$ for a comparative study as described by Lima et al. (2014).

\section{SEM Analysis}

Surface images of raw and pretreated biomasses were obtained by SEM ( $\Sigma$ IGMA-VP, Carl Zeiss, Germany) at IASST, Paschim Boragoan, Guwahati. Samples were prepared by mounting them on specimen aluminum stubs using double-coated tape prior to coating with gold-palladium on SC7640 Suto/Manual Highresolution Sputter Coater (Quorum Technologies, Newhaven, UK). Images were taken at a voltage of $5.00 \mathrm{kV}$ and magnifications between $\times 350$ and $\times 3.00 \mathrm{k}$.

\section{FTIR Spectroscopy}

Spectra of all the samples were obtained in duplicates using the potassium bromide (KBr) disk method. The pellets were prepared by mixing a $2 \mathrm{mg}$ of sample in $100 \mathrm{mg}$ of spectroscopic grade $\mathrm{KBr}$ in an agate mortar. The spectra were collected in the range from 4,000 to $400 \mathrm{~cm}^{-1}$ over 32 scans on NICOLET 6700 FT-IR (Thermo Scientific) at IASST, Paschim Boragoan, Guwahati. A comparative study in the change of spectrum for each biomass prior and after subjecting to pretreatments was analyzed by using Origin 6.1 software. The spectrum wavenumbers in the range of $800-1,800 \mathrm{~cm}^{-1}$ were selected for the PCA variables. The pretreatments: hydrothermally treated, $\mathrm{NaOH}$-treated along with the native substrates were the variables applied for the grouping. The PCA used 18 samples, 521 variables, and the covariance matrix. Function prcomp of inbuilt package "stats" in "R" software was used to calculate the PCA.

\section{Estimation of Monosaccharide and Disaccharide in LCB by HPLC}

Monosaccharide and disaccharide analysis were performed by HPLC (Agilent HPLC 1200 Series) using Aminex HPX-87H anion-exchange column $(300 \times 7.8 \mathrm{~mm}$, Bio-Rad $)$ equipped with cation- $\mathrm{H}$ guard cartridge (Bio-Rad). The filtered $(0.45 \mu \mathrm{m}$ pore size, Millipore) and degassed mobile phase $\left(5 \mathrm{mM} \mathrm{H}_{2} \mathrm{SO}_{4}\right)$ was used at a constant flow rate of $0.6 \mathrm{~mL} / \mathrm{min}$ with the column and refractive index detector temperatures maintained at 40 and $50^{\circ} \mathrm{C}$, respectively. Standards of the monosaccharides and disaccharides (Absolute Standards, USA) at $0.2-1 \mathrm{~g} / \mathrm{L}$ were separated individually and were quantified using external calibration with an equimolar mixture (cellobiose, glucose, xylose, and arabinose) and areas obtained were used to calculate the concentration of monosaccharides and disaccharide in the test samples (both untreated and pretreated).

\section{Analysis of Inhibitors in LCB by HPLC}

Liquor fractions obtained from each pretreatment with the native substrates were filtered through $0.45 \mu \mathrm{m}$ pore size membrane filter, prior subjection to HPLC analysis equipped with Aminex HPX-87H column, and RID. HPLC was operated at $50^{\circ} \mathrm{C}$ using $0.45 \mu \mathrm{m}$ filtered $5 \mathrm{mM} \mathrm{H}_{2} \mathrm{SO}_{4}$ as mobile phase at a constant flow rate of $0.6 \mathrm{~mL} / \mathrm{min}$. Standard curves were generated using furfural, acetic acid, and hydroxymethylfurfural (HMF) (Absolute Standards, USA) in the concentration ranges from 0.2 to $1 \mathrm{~g} / \mathrm{L}$.

\section{Enzymatic Hydrolysis}

Both pretreated and the native (untreated) substrates were enzymatically hydrolyzed using commercial cellulase enzyme (ONOZUKAR-10, Hi-Media, India) and cellobiase from Aspergillus niger (Novozyme 188, Bagsvaerd, Denmark). The solid loading for enzymatic hydrolysis was $8 \mathrm{mg}$. The saccharification was performed for the substrates in a total volume of $1,200 \mu \mathrm{L}(0.05 \mathrm{M}$ citrate buffer $)$ in a $2 \mathrm{~mL}$ centrifuge tube for $8 \mathrm{~h}$, with an enzyme loading of $20 \mathrm{FPU} / \mathrm{g}$ and $1 \mathrm{U} / \mathrm{g}$ of the biomass of ONOZUKAR-10 and Novozymes 188, respectively. The enzymatic hydrolysis was performed at $50^{\circ} \mathrm{C}$ maintaining the $\mathrm{pH} 4.8$ in a shaker incubator operated at $250 \mathrm{rpm}$ (Thermomixer comfort, Eppendorf). Streptomycin sulfate $(2.5 \mathrm{mg} / 6 \mathrm{~g}$ of substrate) was also added to avoid microbial contamination during enzymatic hydrolysis. The reducing sugars released during the enzymatic hydrolysis was monitored and estimated by the DNS method (Miller, 1959).

\section{Fermentation}

For fermentation experiments, MTCC 1755 (Fusarium oxysporum) was grown on PDA plates at $28^{\circ} \mathrm{C}$ for 7 days. Four disks of $0.3 \mathrm{~cm}^{2}$ of mycelial mat from the periphery were harvested and transferred aseptically to a $100 \mathrm{~mL}$ Erlenmeyer flask individually for each substrate in their native and hydrothermally treated form viz. sugarcane BG, ficus fruits (FF), cassava aerial parts (CS), and RS as sole carbon sources containing $30 \mathrm{~mL}$ T1 medium $(20 \mathrm{~g} / \mathrm{L}$ carbon source, $1 \mathrm{~g} / \mathrm{L}$ yeast extract, $10 \mathrm{~g} / \mathrm{L} \mathrm{KH}_{2} \mathrm{PO}_{4}, 2 \mathrm{~g} / \mathrm{L}\left(\mathrm{NH}_{4}\right)$ $\mathrm{SO}_{4}$, and $0.5 \mathrm{~g} / \mathrm{L} \mathrm{MgSO}_{4} .7 \mathrm{H}_{2} \mathrm{O}, \mathrm{pH} 5.2$ ) for fermentation at $28^{\circ} \mathrm{C}$ for 7 days at static conditions. Analysis of ethanol was conducted using Trace GC Ultra, Thermo Fisher, equipped with a TR-V1wax $30 \mathrm{~m}$ column (Thermo Fisher, ID $0.25 \mathrm{~mm} \times 1.40 \mu \mathrm{m}$ film), on column injector, and FID conditions; $250^{\circ} \mathrm{C} ; \mathrm{H}_{2}, 25$ PSI, equivalent to $25 \mathrm{~mL} / \mathrm{min}$; air, $2 \mathrm{PSI}$, equivalent to $100 \mathrm{~mL} / \mathrm{min}$; gain set to "medium" in a split ratio of 1:18. Each injection was repeated thrice, ethanol routinely came out at retention time equivalent to $65^{\circ} \mathrm{C}$.

\section{RESULTS}

\section{Biomass Composition}

Soluble extractives, cellulose, hemicellulose, and lignin contents of the six feedstocks are presented in Table 1. The content of solubles in BG and RS is low. The cellulose content of CS, FF, RS, and Loktak PH was more than that of sugarcane BG. Hemicellulose content was highest in sugarcane BG followed 
TABLE 1 | Composition of selected lignocellulosic biomass (LCB) available in Indo-Burma biodiversity Hotspots.

\begin{tabular}{|c|c|c|c|c|c|}
\hline \multirow[t]{2}{*}{ LCB } & \multicolumn{5}{|c|}{ Components of the biomass (\%) } \\
\hline & Solubles & Cellulose & Hemicellulose & Lignin & Others \\
\hline Sugarcane bagasse & $3.55 \pm 0.29$ & $32.06 \pm 0.22$ & $29.20 \pm 0.73$ & $23.30 \pm 0.18$ & $11.85 \pm 1.05$ \\
\hline Cassava & $3.90 \pm 0.63$ & $34.28 \pm 0.79$ & $24.38 \pm 0.28$ & $20.65 \pm 0.61$ & $16.77 \pm 0.98$ \\
\hline Loktak Phumdi & $12.21 \pm 0.20$ & $25.41 \pm 0.43$ & $20.59 \pm 0.39$ & $21.20 \pm 0.58$ & $20.56 \pm 1.39$ \\
\hline Sawdust & $4.45 \pm 0.16$ & $35.28 \pm 0.43$ & $28.57 \pm 0.68$ & $24.97 \pm 0.30$ & $6.71 \pm 0.36$ \\
\hline Ricestraw & $3.38 \pm 0.51$ & $33.81 \pm 0.58$ & $25.12 \pm 0.65$ & $19.54 \pm 0.48$ & $18.13 \pm 0.82$ \\
\hline Ficus fruits & $4.67 \pm 0.57$ & $34.09 \pm 0.41$ & $25.25 \pm 0.62$ & $17.17 \pm 0.73$ & $18.74 \pm 0.98$ \\
\hline
\end{tabular}

Data represented are the averages of the results from duplicated experiments and each LCB had three replications (bar indicates \pm SD).

by SD, FF, RS, and CS. Cellulose and hemicellulose content was lowest in Loktak PH. Cellulose content of FF, RS, and cassava was similar and comparable with sugarcane BG, which is a major LCB feedstock for bioethanol industry. In this study, lignin content of the FF was lowest $(17.17 \pm 0.73 \%)$ and highest in $\operatorname{SD}(24.97 \pm 0.30 \%)$.

\section{Study on Morphological Changes Produced by Pretreatment}

The morphological changes brought about by hydrothermal pretreatment on biomass substrates in comparison with $\mathrm{NaOH}$ pretreatment at $130^{\circ} \mathrm{C}$ was investigated employing SEM. The effects of both pretreatments on sugarcane BG in comparison with the raw material are depicted in Figure 1. The surface of native sugarcane BG (A), and their counterpart hydrothermally pretreated BG (B) did not show any marked difference except with an appearance of few droplets like structures. However, after alkali pretreatment $(\mathrm{C})$, changes in terms of the disappearance of smooth covering accompanied by fragmentation and fibrillation more than native was evident with higher numbers of droplets like structures.

The surface of the untreated cassava (D) was intact with an uneven covering layer. Upon hydrothermally treated, the surface became swollen and fibrillated causing the surface partially fragmented. However, $\mathrm{NaOH}$ pretreatment led to more swollen and deformed and it seems to affect the surface with a smoother visual aspect. The hydrothermally and $\mathrm{NaOH}-$ treated FF surface appeared to be fragmented like network structures when compared with the surface of the untreated raw material. The FF surface of $\mathrm{NaOH}$-treated became more swollen when compared with hydrothermally pretreated FF substrate.

There is no conspicuous difference observed in the case of untreated and hydrothermally pretreated $\mathrm{PH}$, however, the surface of the $\mathrm{NaOH}$-treated substrate appeared smooth and swollen. The morphology of the RS that was subjected to hydrothermal and $\mathrm{NaOH}$ pretreatment presented subtle differences with the development of disrupting pores which tend to appear swollen in $\mathrm{NaOH}$ pretreated in comparison with the untreated RS. The morphologies of untreated and hydrothermally pretreated SD were more or less similar with distinguished cracked pores and disorganized attributes in the latter. In the case of $\mathrm{NaOH}$ pretreated SD, the dismantled structure appeared more polished and swollen.

\section{FTIR Analysis}

The chemical structural changes in treated biomass compared with their respective raw biomass (untreated) were investigated through application of FT-IR. The fingerprint region of the FT-IR spectra depicting the structural changes of the hydrothermally, $\mathrm{NaOH}$ pretreated and, the untreated substrates of the six substrates are shown in Figure 2. In both pretreatments with respect to native substrates, there is incremental of the curves in asymmetry and line width within the range of 3,800-3,000 $\mathrm{cm}^{-1}$. There is marginally diminished in relative absorbance in all the pretreated samples around $2,900 \mathrm{~cm}^{-1}$. An interesting change was that the distinct absorption peak at $1,738 \mathrm{~cm}^{-1}$ associated with hemicellulose disappeared in all the alkali-treated samples. Two apparent bands were detected in the case of untreated substrates around 1,735 and 1,241 $\mathrm{cm}^{-1}$ related to hemicelluloses. Several intense bands were clearly evident in the spectra at 1,603, 1,509, 1,430 , and $1,460 \mathrm{~cm}^{-1}$ for lignin moieties in the controls and hydrothermally pretreated samples.

\section{Principal Component Analysis of the FT-IR Spectrum}

The variance explained by the PCA using the two initial principal components PC1 and PC2 were $90.95 \%$ with a PC1 contribution of $79.66 \%$ and PC2 of $11.29 \%$. PC1 and PC2 loading plots (Figure 3A) distinguished the most significant wavenumbers in terms of variability explained by each principal component. PC1 did not exhibit negative loadings for any of the wavenumbers; meanwhile, PC2 has exhibited both the negative and positive loadings. In both cases, different minimum and maximum points were possible to identify both the principal components. The signals perceived between 800 and $1,200 \mathrm{~cm}^{-1}$ was the lowest point in $\mathrm{PC} 1$; meanwhile, in PC2, it was the highest point from 800 to $980 \mathrm{~cm}^{-1}$ and lowest range from 1,000 to $1,200 \mathrm{~cm}^{-1}$. This wavenumber range has been connected with different types of cellulose, essentially an indication of the fact that the treatments had brought changes on the various biomass samples. The other significant signal was $864 \mathrm{~cm}^{-1}$; this was a minimum signal exhibited lowest in PC1 and this corresponded with the $\mathrm{NaOH}$ signals found in the FTIR spectrum. The PC2 loadings which captured $11.29 \%$ of the variance show prominent peaks at spectral regions 1,515 and $1,733 \mathrm{~cm}^{-1}$ positively, whereas $1,247,1,325,1,425,1,580$, and $1,603 \mathrm{~cm}^{-1}$ were negatively perceived in association with functional groups related to lignin moieties. The scores plot 

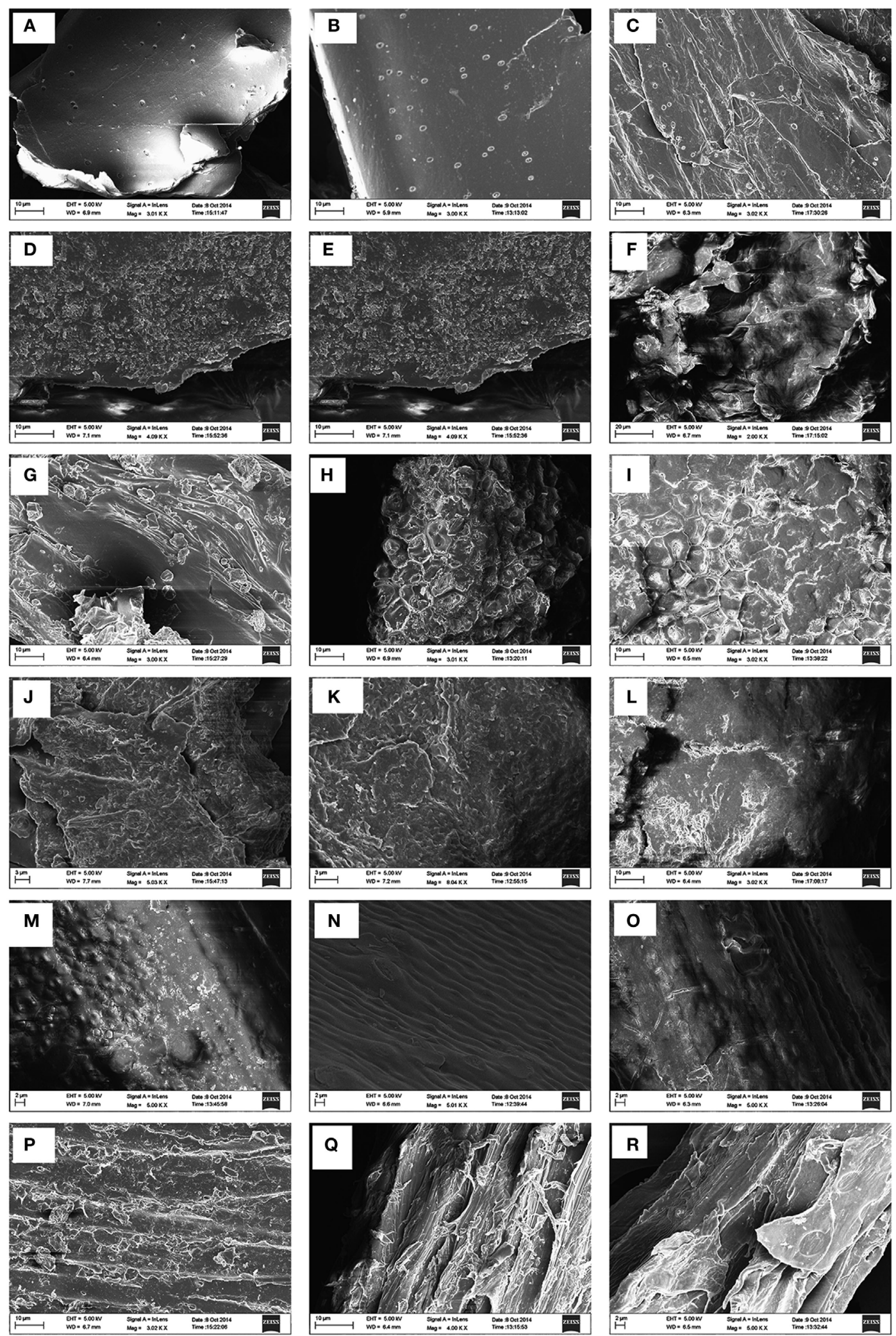

FIGURE 1 | Scanning electron microscopy images of six types of lignocellulosic biomass. First row: sugarcane bagasse; second row: cassava aerial parts; third row: ficus fruits; fourth row: Loktak phumdi; fifth row: rice straw; and sixth row: sawdust. Untreated: (A,D,G,J,M,P); hydrothermally pretreated: (B,F,H,K,N,Q); sodium hydroxide pretreated: (C,E,I,L,O,R) 

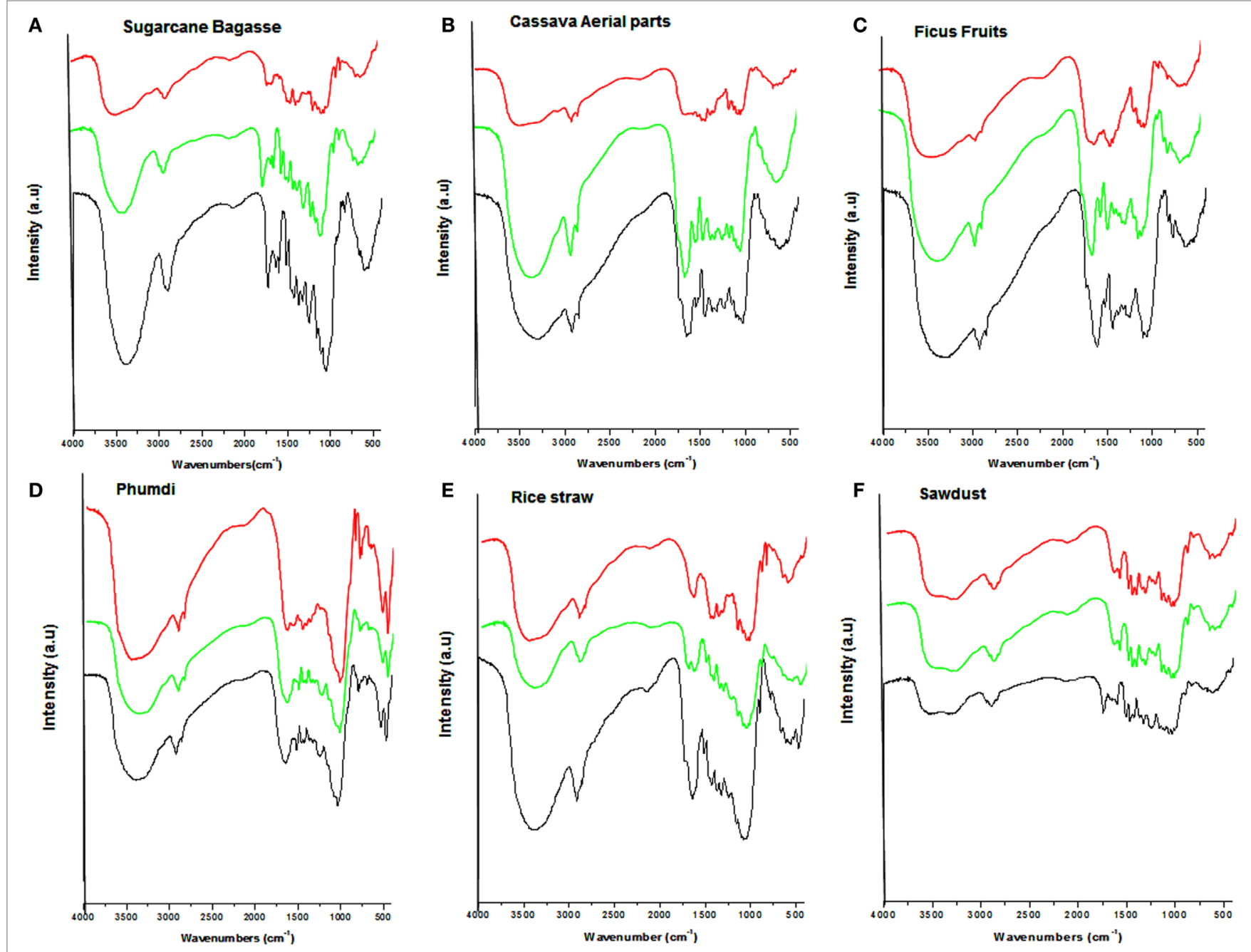

FIGURE 2 | Fourier transform infrared spectra of six types of lignocellulosic biomass. The red, green, and black lines indicate sodium hydroxide treated, hydrothermally treated, and untreated, respectively. (A) Sugarcane bagasse, (B) cassava aerial parts, (C) ficus fruits, (D) Phumdi, (E) rice straw, and (F) sawdust.

generated through PCA shows that the pretreatments broadly resulted in three clusters (Figure 3B).

\section{Soluble Fraction Analysis: Monosaccharides and Inhibitors}

A number of desirable products (monosaccharides and disaccharides) and the potential inhibitors such as furfural, HMF, and acetic acid formed as a result of pretreatments, both by hydrothermal and sodium hydroxide of all the six feedstocks in liquor fractions are presented (Figure 4; Table 2). Among the monosaccharides, glucose was the most common and in higher concentration in soluble fractions obtained from most of the biomasses, followed by xylose and arabinose (Figure 4). The concentration of these monosaccharides in the soluble fractions of sugarcane BG, CS, and FF was much higher than those in the other three biomasses. Hydrothermal treatment increased the concentration of glucose in the soluble fractions of three biomasses conspicuously and cellobiose concentration (Figure 4) was increased conspicuously only of sugarcane BG. In contrast, $\mathrm{NaOH}$ pretreatment reduced the concentrations drastically except that of glucose in FF. The content of three major inhibitors in liquor fraction of untreated and pretreated LCB is presented in Table 2. Content of acetic acid in differently treated LCB varied from 7.17 to $143.28 \mathrm{mg} / \mathrm{L}, \mathrm{HMF}$ from below detection level (BDL) to $28.33 \mu \mathrm{g} / \mathrm{L}$, and furfural BDL to $111.06 \mu \mathrm{g} / \mathrm{L}$ (Table 2).

\section{Enzymatic Saccharification of the Pretreated Biomasses}

Enzymatic hydrolysis released varying quantity of sugars from the solid fractions (after removal of the liquid fraction) of the six untreated biomasses. Reducing sugar released from sugarcane BG, CS, and FF were more than those from the other biomasses (Figure 5). Pretreatments of the biomass enhanced release of sugar and saccharification efficacy. The saccharification efficiency of hydrothermally treated substrates and the sodium hydroxide-treated substrates significantly increased, 

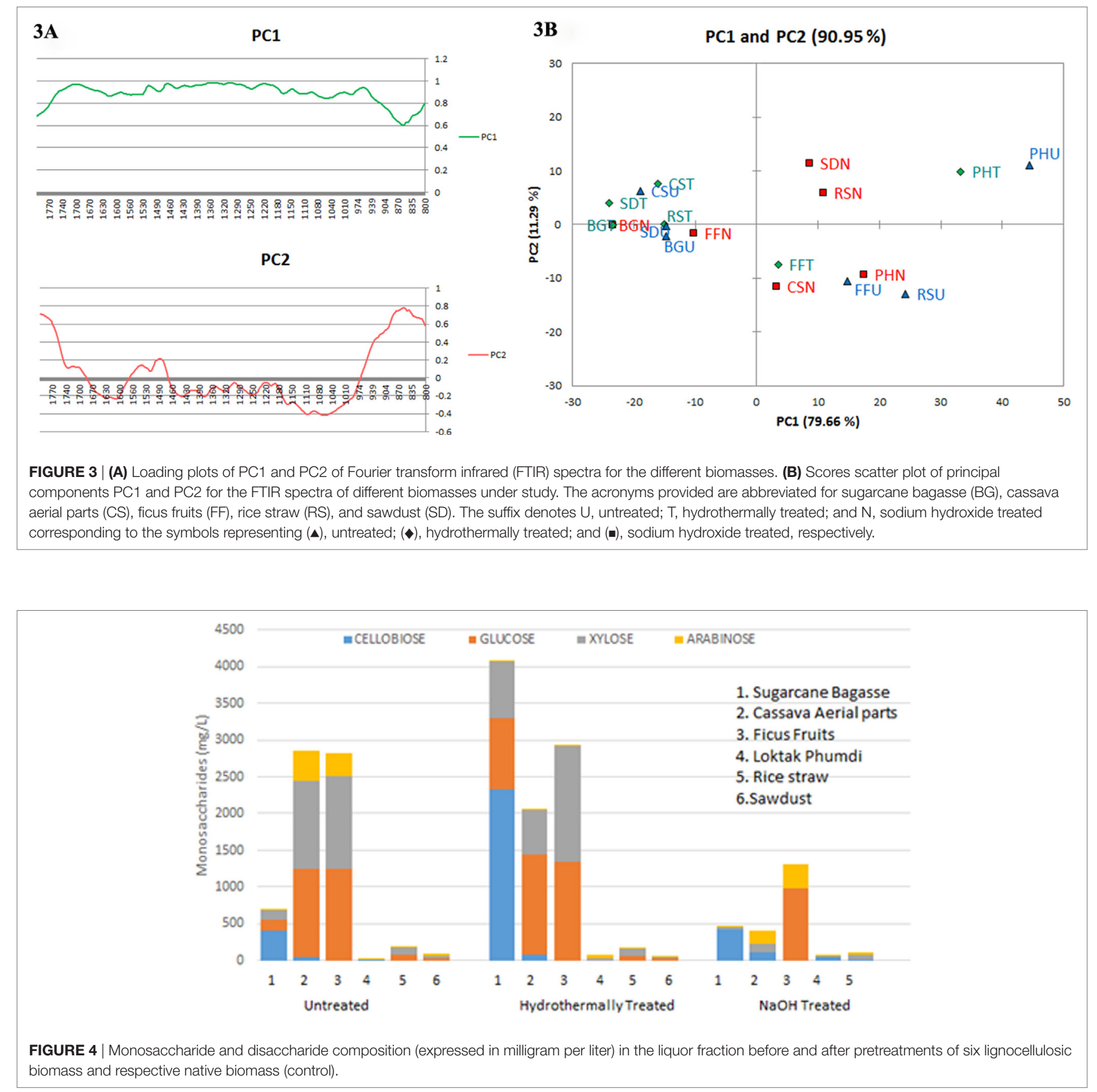

ranging from 1.35 to $28.64 \%$ and from 3.24 to $30.27 \%$, respectively, against a range of $0.81-17.97 \%$ (Figure 5) of the native substrates.

\section{Ethanol Production}

The fermentation performance of MTCC 1755 (F. oxysporum) was preliminarily investigated on the four selected substrates both in their native as well as hydrothermally pretreated state as the sole carbon source without the addition of any extraneous enzymes. The CBP of the selected substrates demonstrated highest ethanol titer of $0.85 \mathrm{~g} / \mathrm{L}$ in hydrothermally treated sugarcane BG which corresponded to ethanol yield of $0.042 \mathrm{~g} / \mathrm{g}$ of substrate obtained $23.43 \%$ of maximum theoretical ethanol yield. Similarly, maximum ethanol concentrations of $0.66,0.76$, and $0.62 \mathrm{~g} / \mathrm{L}$, corresponding to ethanol yields of $0.033,0.038$, and $0.031 \mathrm{~g}$ ethanol per gram of substrate utilized, respectively, were attained in hydrothermally treated CS, FF, and RS (Figure 6). Among the untreated biomass, CS attained highest ethanol titer of $0.83 \mathrm{~g} / \mathrm{L}$ followed by RS, FF, and sugarcane BG within 96-144 h of fermentation (Figure 6). 
TABLE 2 | Content of three major inhibitors in liquor fraction of six lignocellulosic biomass (LCB) before (control) and after hydrothermal and sodium hydroxide $(\mathrm{NaOH})$ pretreatments.

\begin{tabular}{|c|c|c|c|c|}
\hline LCB & Treatment & $\begin{array}{c}\text { Acetic acid } \\
(\mathrm{mg} / \mathrm{L})\end{array}$ & HMF ( $\mu \mathrm{g} / \mathrm{L})$ & $\begin{array}{c}\text { Furfural } \\
\text { ( } \mu \mathrm{g} / \mathrm{L})\end{array}$ \\
\hline $\begin{array}{l}\text { Sugarcane } \\
\text { bagasse }\end{array}$ & $\begin{array}{l}\text { Untreated } \\
\text { (control) }\end{array}$ & $7.17 \pm 0.25$ & $0.2 \pm 0.01$ & $3.5 \pm 0.41$ \\
\hline $\begin{array}{l}\text { Sugarcane } \\
\text { bagasse }\end{array}$ & Hydrothermal & $88.54 \pm 2.05$ & $\mathrm{BDL}$ & $5.84 \pm 0.13$ \\
\hline $\begin{array}{l}\text { Sugarcane } \\
\text { bagasse }\end{array}$ & $\mathrm{NaOH}$ & $128.09 \pm 1.49$ & $\mathrm{BDL}$ & $4.62 \pm 0.30$ \\
\hline $\begin{array}{l}\text { Cassava aerial } \\
\text { parts }\end{array}$ & $\begin{array}{l}\text { Untreated } \\
\text { (control) }\end{array}$ & $27.19 \pm 0.73$ & $28.33 \pm 0.94$ & $\mathrm{BDL}$ \\
\hline $\begin{array}{l}\text { Cassava aerial } \\
\text { parts }\end{array}$ & Hydrothermal & $50.35 \pm 0.87$ & $9.96 \pm 0.04$ & $\mathrm{BDL}$ \\
\hline $\begin{array}{l}\text { Cassava aerial } \\
\text { parts }\end{array}$ & $\mathrm{NaOH}$ & $52.04 \pm 0.51$ & $0.22 \pm 0.008$ & $111.06 \pm 0.9$ \\
\hline Ficus fruits & $\begin{array}{l}\text { Untreated } \\
\text { (control) }\end{array}$ & $86.12 \pm 0.53$ & $1.23 \pm 0.004$ & $\mathrm{BDL}$ \\
\hline Ficus fruits & Hydrothermal & $143.28 \pm 0.61$ & $6.23 \pm 0.04$ & $16.53 \pm 0.24$ \\
\hline Ficus fruits & $\mathrm{NaOH}$ & $31.84 \pm 0.54$ & $0.21 \pm 0.01$ & BDL \\
\hline Loktak Phumdi & $\begin{array}{l}\text { Untreated } \\
\text { (control) }\end{array}$ & $12.06 \pm 0.26$ & $0.13 \pm 0.008$ & $0.36 \pm 0.01$ \\
\hline Loktak Phumdi & Hydrothermal & $42.8 \pm 0.61$ & $8.93 \pm 0.04$ & $\mathrm{BDL}$ \\
\hline Loktak Phumdi & $\mathrm{NaOH}$ & $33 \pm 0.54$ & $0.84 \pm 0.01$ & $\mathrm{BDL}$ \\
\hline Ricestraw & $\begin{array}{l}\text { Untreated } \\
\text { (control) }\end{array}$ & $53.34 \pm 0.43$ & $0.36 \pm 0.021$ & $\mathrm{BDL}$ \\
\hline Ricestraw & Hydrothermal & $145.78 \pm 0.53$ & $16.53 \pm 1.11$ & $\mathrm{BDL}$ \\
\hline Ricestraw & $\mathrm{NaOH}$ & $65.86 \pm 0.22$ & $7.36 \pm 0.16$ & $\mathrm{BDL}$ \\
\hline Sawdust & $\begin{array}{l}\text { Untreated } \\
\text { (control) }\end{array}$ & $21.03 \pm 0.63$ & $1.03 \pm 0.12$ & $\mathrm{BDL}$ \\
\hline Sawdust & Hydrothermal & $43.24 \pm 0.28$ & $17.7 \pm 0.16$ & $56.78 \pm 1.49$ \\
\hline Sawdust & $\mathrm{NaOH}$ & $100.51 \pm 0.49$ & $0.054 \pm 0.003$ & BDL \\
\hline
\end{tabular}

$H M F$, hydroxymethylfurfural; $B D L$, below detection level.

Data represented are the averages of the results of three replicate samples (bar indicates $\pm S D$ ).

\section{DISCUSSION}

Exploitation of second-generation biofuels depends on the production of LCB from non-agricultural lands in a sustainable manner and also their availability round the year. Availability of the five feedstocks viz. CS, FF, RS, Loktak PH (floating biomass), and SD is such that they can support biomass-based bioethanol production in NERI round the year. Analysis of the composition of this biomass and change in morphology, chemical composition, and saccharification as a result of their pretreatments with hydrothermal and sodium hydroxide has generated interesting results which are discussed below.

\section{Biomass Composition}

As expected yield of the soluble content in BG procured for our experiment was low $(3.5 \pm 0.29 \%)$ due to their excessive washing during commercial extraction. Soluble content in RS of our study was low. Soluble content in RS and in many other grass varieties is generally low and it is attributed to richness of silica content (Eika, 2014). PH, the floating biomass, is a heterogeneous aggregate of soil, vegetation, and organic matters at various phases of decomposition that has transformed into a dense solid form which might have attributed to its soluble content of $12.21 \pm 0.20 \%$ (Table 1). Lignin content in feedstocks is an important barrier in cellulose accessibility. Lignin is a complex polymer of phenylpropane units (sinapyl, p-coumaryl, and coniferyl alcohol) that acts as a cementing and waterproofing agent in plant cell wall. It is generally considered to be a physical barrier in achieving efficient saccharification of biomass (Gunjkar et al., 2001; Berlin et al., 2005; Nlewem and Thrash, 2010). Despite high cellulose content in SD, its high lignin content appears to make it less suitable feedstock.

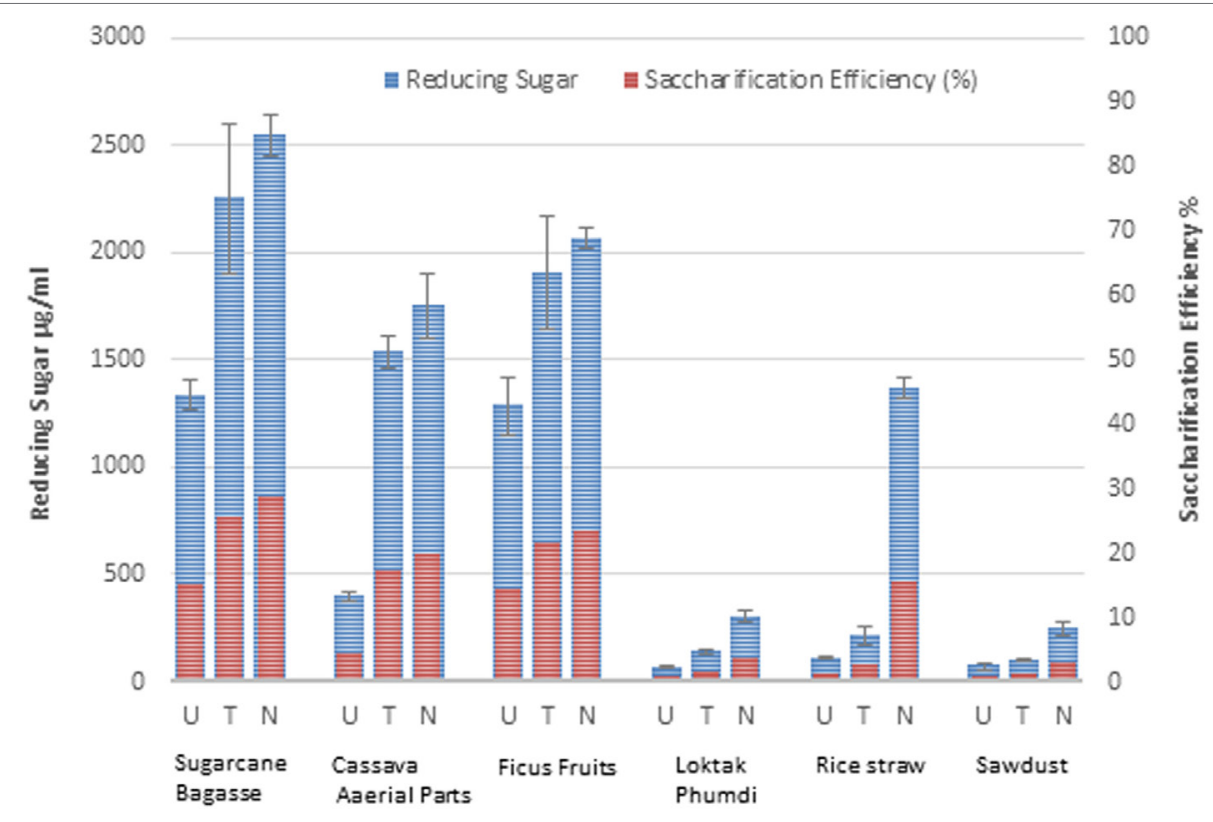

FIGURE 5 | Reducing sugar yield (microgram per milliliter) and saccharification efficiency (\%) of six different types of lignocellulosic biomass. U, untreated; $\mathrm{T}$, hydrothermally treated; $\mathrm{N}, \mathrm{NaOH}$-treated are indicated. Data represented are the averages of the results from duplicated experiments (bar indicates $\pm \mathrm{SD}$ ). 

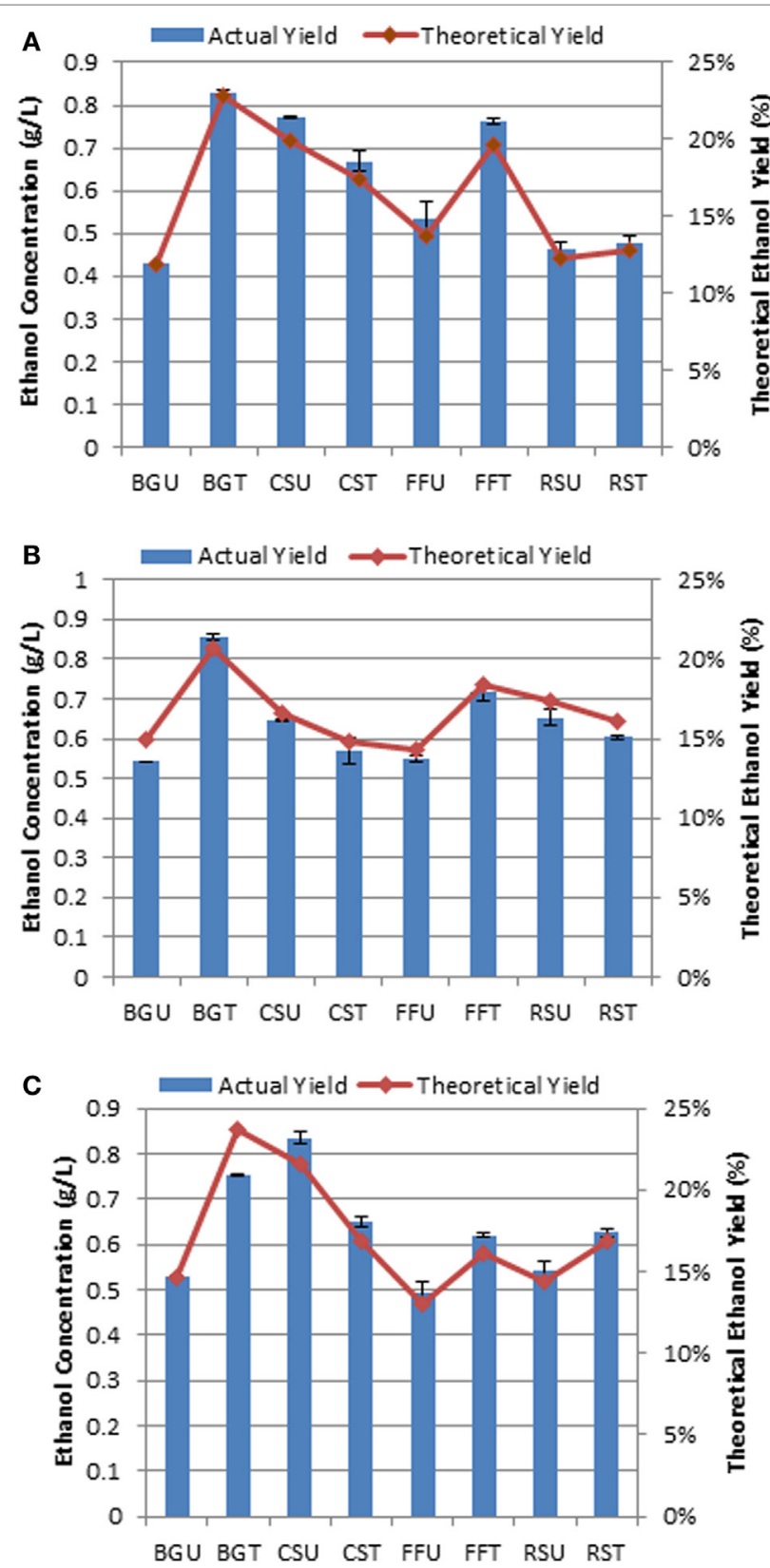

FIGURE 6 | Fermentation of selected lignocellulosic substrates for bioethanol production and estimated at three intervals (A) $96 \mathrm{~h}$, (B) $120 \mathrm{~h}$, and (C) $144 \mathrm{~h}$. BGU, untreated sugarcane bagasse; BGT, hydrothermally treated sugarcane bagasse; CSU, untreated cassava aerial parts; CST,

hydrothermally treated cassava aerial parts; FFU, untreated ficus fruits; FFT, hydrothermally treated ficus fruits; RSU, untreated rice straw; RST, hydrothermally treated rice straw. Bar indicates \pm SD.

\section{Study on Morphological Changes Produced by Pretreatment}

The effect of alkali pretreatment of sugarcane BG is evident with the disappearance of smooth covering accompanied by fragmentation and fibrillation compared with untreated BG with the appearance of a higher number of droplets like structures.
This may be associated with high level of hemicellulose removal by sodium hydroxide, thereby enabling more accessibility of the enzyme to the cellulose fiber. Furthermore, droplets observed on the surface of the $\mathrm{NaOH}$-treated sugarcane $\mathrm{BG}$ could be due to the generation of some residues associated with lignin modifications and precipitation which was specific to only sugarcane BG. Similar observation was reported previously (Lima et al., 2014). These results reflect the effect of the different pretreatments on the morphology of different biomass samples as a result of solubilization of lignin and hemicelluloses. Thus, pretreatments seem to increase the surface area and comparative changes for enhanced enzyme accessibility. It is also evident that a more disorganized structure develops as a result of the pretreatments application upon the biomass substrates compared with the raw material (untreated). The droplets visualized in our study exhibited similar physical features as described in earlier studies (Selig et al., 2007; Donohoe et al., 2008; Li et al., 2014) and they are presumed to be pseudo-lignin derived from carbohydrate like xylan during the course of severe hydrothermal pretreatment (Kumar et al., 2013; Pu et al., 2013).

Sodium hydroxide causes cleavages of the alpha-aryl ester bonds mechanistically with the weakening of hydrogen bonds from its polyphenolic monomers, which in turn promotes swelling of cellulose (Rocha et al., 2012). This was also evident in the case of all the biomass samples of this study, pretreated with sodium hydroxide. The sodium hydroxide solution causes swelling of plant cell wall and disrupts the lignin structure, reduces the degree of crystallinity, and polymerization of cellulose, accompanied by the increase in surface area of cellulose (Taherzadeh and Karimi, 2008). The similar morphological change was evident in the alkaline post-treated sweet sorghum stem when compared with the corresponding hydrothermally pretreated substrates (Sun et al., 2015). Both the hydrothermal and $\mathrm{NaOH}$ pretreatments resulted in evident damage to the cell structure in the six biomasses, which would result in enhanced enzymatic digestibility of the pretreated samples owing to a more available surface area for easy enzyme accessibility and efficient saccharification.

\section{FT-IR Analysis}

The incremental of the curves in asymmetry and line width within the range of $3,800-3,000 \mathrm{~cm}^{-1}$ from both treatments with respect to native substrate suggest dislocations imparted from the treatments in the crystalline structure of cellulose. The band absorption around $3,430 \mathrm{~cm}^{-1}$ is assigned to the stretching of $\mathrm{O}-\mathrm{H}$ groups of $\mathrm{H}$-bonds of cellulose (Buranov and Mazza, 2010). The reduction in intensity exhibited by the peak upon subjection to hydrothermal and $\mathrm{NaOH}$ pretreatment might be due to disruption of hydrogen bonds in cellulose. The band position around $2,900 \mathrm{~cm}^{-1}$ is ascribed to $\mathrm{C}-\mathrm{H}$ stretching within the methylene portions of the cellulose (Kumar et al., 2009). The marginal diminished in relative absorbance in all the pretreated samples was indicative of slight rupture of the methyl and methylene portions of cellulose. The region extending between 1,100 and $1,200 \mathrm{~cm}^{-1}$ contributes to large portions related to cellulose and hemicellulose with a maximal value around 1,164 and $1,035 \mathrm{~cm}^{-1}$ owing to asymmetrical stretching of $\mathrm{C}-\mathrm{O}-\mathrm{C}$ and $\mathrm{C}-\mathrm{O}$, respectively (Pandey, 
1999, 2005; Colom et al., 2003). The vicinity about 1,247 $\mathrm{cm}^{-1}$, a characteristic of hemicellulose and lignin component in the FTIR spectra of the biomass was ascribable to the stretching of $\mathrm{C}-\mathrm{O}$ (Pandey and Pitman, 2003). The band around $1,515 \mathrm{~cm}^{-1}$ is observed which is ascribed to $\mathrm{C}=\mathrm{C}$ stretching of the aromatic ring in lignin (Colom et al., 2003; Pandey, 2005). A characteristic of $C=O$ stretching of the unconjugated hemicellulose band is reported around $1,733 \mathrm{~cm}^{-1}$. The disappearance of the band at $1,738 \mathrm{~cm}^{-1}$ revealed that alkaline treatment cleaved the ester bonds of hemicelluloses, such as acetyl and uronic-ester groups in all of the alkali-treated samples (Sun and Tomkinson, 2002). Two apparent bands were detected in the case of untreated substrates around 1,735 and $1,241 \mathrm{~cm}^{-1}$ attributable to $\mathrm{C}=\mathrm{O}$ and $\mathrm{C}-\mathrm{O}$ stretching vibrations at the acetyl ester unit of hemicelluloses (Owen and Thomas, 1989; Chen et al., 1997; Gastaldi et al., 1998; Kumar and Wyman, 2009). However, a gradual diminishing of intensities in the two bands in both the hydrothermally and $\mathrm{NaOH}$ pretreated substrates was ascribed to the deacetylation with the removal of hemicelluloses. Several intense bands were clearly evident in the spectra at 1,603, $1,509,1,430$, and $1,460 \mathrm{~cm}^{-1}$ for lignin of the controls and hydrothermally pretreated substrates, revealing incomplete removal of lignin on the subjection of the substrates to hydrothermal pretreatment. Similar observations were also seen in sweet sorghum stems after hydrothermal pretreatment (Sun et al., 2014). The intensities of the lignin bands in $\mathrm{NaOH}$ pretreated substrates show an acute reduction in the spectra in comparison with the untreated and the hydrothermally pretreated substrates, an indication in the effective removal of lignin through alkaline delignification.

\section{Principal Component Analysis of the FT-IR Spectrum}

The loadings plots (Figure 3A) obtained are complicated, suggesting that the alterations concerning different groups of bands emerged on subjection to pretreatments from the scores result. It affirms, however, that the main loadings observed are located at 1,030 and $1,050 \mathrm{~cm}^{-1}$ ( $\mathrm{C}-\mathrm{O}$ stretching in different groups of carbohydrates); 1,164 and $1,375 \mathrm{~cm}^{-1}(\mathrm{C}-\mathrm{O}-\mathrm{C}$ and $\mathrm{C}-\mathrm{H}$ vibrations or deformation in cellulose and hemicellulose); 1,458 and $1,515 \mathrm{~cm}^{-1}(C-H$ deformation in carbohydrates and lignin and $C=C$ vibrations in lignin). Thus, it is apparent that PC1 mostly pertains with portions of the spectra related with carbohydrates. The PC2 loadings which captured $11.29 \%$ of the variance show prominent peaks at spectral regions 1,515 and $1,733 \mathrm{~cm}^{-1}$ positively, whereas $1,247,1,325,1,425,1,580$, and $1,603 \mathrm{~cm}^{-1}$ were negatively perceived in association with functional groups related to lignin moieties suggestive of higher amounts of lignin in biomasses. The scores plot (Figure 3B) generated through PCA shows that the pretreatments broadly created three clusters viz., (a) untreated cassava, sugarcane BG, and $\mathrm{SD}$; (b) hydrothermally treated cassava, sugarcane BG, and SD; (c) RS along with alkali-treated FF, and sugarcane BG. Assuming uniform composition of all biomass, it was expected that each of native, $\mathrm{NaOH}$ - and hydrothermal-treated form of biomass will separate in three clusters. But rather PCA created cluster based on FT-IR spectra irrespective of the type of biomass or their pretreatments. As a result due to effect of pretreatments, some type of comparable FT-IR spectral pattern between untreated substrates emerged and this may be attributed to the heterogeneous nature of the six types of biomasses. This result has been useful in the selection of a combination of pretreatment type and substrate for subsequent enzymatic saccharification.

\section{Soluble Fraction Analysis: Monosaccharides and Inhibitors}

In the present study, the fall in monosaccharides and disaccharides in soluble fractions is clearly evident in the case of all $\mathrm{NaOH}$ pretreated biomasses, which can be explained by the enhanced formation of inhibitors, particularly acetic acid. However, it is worth mentioning that o-Toluidine reagent was used to estimate total cellulose (glucose equivalents) and hemicellulose (xylose equivalents) content of the untreated biomasses at the initial stage of the experiment, whereas due to availability of HPLC at later stage, the monosaccharides (arabinose, glucose, and xylose), disaccharide (cellobiose), and inhibitors (acetic acid, furfural, and $\mathrm{HMF}$ ) in untreated and pretreated biomasses determination was more precise. Therefore, interpretations of our result reflect an assumption that estimates of cellulose and hemicellulose by the two methods are similar. Type and concentration of sugar degradation products are determined by the severities of pretreatments. For example, furfural and HMF are formed as a result of pentose and hexose degradation; acetyl content in hemicellulose is hydrolyzed into acetic acid as a consequence of deacetylation (Pu et al., 2013). These degradation products are likely to inhibit the growth of fermenting microorganisms or enzymes involved in bioethanol formation. For example, several workers (Navarro, 1994; Pu et al., 2013) found that acetic acid, furfural, and HMF within the limit of $>10 \mathrm{~g} / \mathrm{L},>3 \mathrm{~g} / \mathrm{L}$, and $>1.3 \mathrm{~g} / \mathrm{L}$, respectively, were not inhibitors to Saccharomyces cerevisiae. The concentrations of these inhibitors formed due to pretreatments of the five biomasses of our study were within the permissible limit. On the other hand, several sugar degradation products, weak organic acids, and phenolic compounds released from lignin degradation have been shown to inhibit both yeast (Sanchez and Bautista, 1988; Larsson et al., 1998) and enzymes (Taherzadeh et al., 2000). In other instances, furfural at low concentrations (Tengborg et al., 2001) was found to increase ethanol yield. Similarly, the maximum theoretical yield of $99 \%$ ethanol was obtained at an acetic concentration of $1.0 \mathrm{~g} / \mathrm{L}$ from the fermentation of pretreated wheat meal and this yield was higher compared with those obtained from fermentation carried out in the absence of acetic acid (Palmqvist et al., 1996). However, at higher concentrations of acetic acid $>10 \mathrm{~g} / \mathrm{L}$ and similarly, furfural at concentrations of $>3 \mathrm{~g} / \mathrm{L}$ reduced the ethanol productivity to a great extent (Navarro, 1994). Thus, standardization of pretreatments of biomasses of this study in terms of quantity of fermentable sugars and inhibitors in the soluble fraction shows that hydrothermally pretreated sugarcane BG, CS, and FF are potential feedstocks for bioethanol production. 
This result suggests that both the pretreatments significantly enhanced the saccharification efficiency of the substrates and $\mathrm{NaOH}$ pretreatment was relatively better than hydrothermal method. This differential effect could be associated with the different composition of hemicellulose and lignin in the biomass samples. Hemicellulose and lignin have been demonstrated to block enzymatic hydrolysis of cellulose. The lower in the proportions of hemicellulose and lignin in the biomass, the higher the value of enzymatic hydrolysis efficiency of cellulose (Mussatto et al., 2008; Erdei et al., 2010). Although there was no conspicuous difference in hemicellulose and lignin content of the native substrates (Table 1), pretreatments resulted in substantial degradation and removal of hemicellulose and lignin as evidenced by the HPLC and FTIR analyses (Figures 2 and 4). Sodium hydroxide pretreatment generates acetic acid from the hydrolysis of the acetyl groups in the hemicelluloses. Therefore, the higher release of acetic acid may be attributed to the hemicellulose content as evident from its highest content in sugarcane BG followed by SD, FF, RS, and cassava (Table 1). It is noteworthy that $\mathrm{NaOH}$ pretreatment caused a very high level of sugar release and saccharification efficiency of RS which are abundantly produced in the region and can be an ideal source to support the production of bioethanol round the year.

\section{Enzymatic Saccharification of the Pretreated Biomasses}

In previous studies, maximum hydrolytic efficiency of cellulose conversion (72\%) was achieved from consecutive acid-base pretreatment of sugarcane BG (Rezende et al., 2011), employing a combination of 25 FPU of Accelerase 150 (DuPont, Wilmington, DE, USA) and $50 \mathrm{IU}$ of $\beta$-glucanase from Novozyme 188 (Sigma Aldrich, USA). Similarly, cellulose conversion range between 27.5 and $47.7 \%$ and 15.9 and $48.8 \%$ was obtained by employing two enzyme preparations cellulase I and cellulase II, respectively, during $24 \mathrm{~h}$ hydrolysis (Santos et al., 2011). Although the hydrolytic efficiency of the biomasses of our study appears to be lower than those reported earlier, it is difficult to make direct comparisons as appropriate enzyme loading and hydrolytic conditions also affect sugars recovery from the substrates (Zhu et al., 2008; Rezende et al., 2011). It will be worthwhile to work out most appropriate enzyme loading and hydrolytic conditions for the superior biomass, i.e., sugarcane BG, CS, FF, and RS of this study to achieve maximum sugar recovery.

\section{Bioethanol Production}

The ethanol yield achieved using MTCC 1755 on hydrothermal and untreated biomass substrates are much lower than those found by other workers under varying conditions (Hossain et al., 2011). For instance, inoculation of Neurospora crassa on $1 \mathrm{~g}$ alkali pretreated brewer's spent grain yielded $0.074 \mathrm{~g}$ and inoculation of F. oxysporum yielded $0.109 \mathrm{~g}$ ethanol (Xiros et al., 2008; Xiros and Christakopoulos, 2009). On the other hand, inoculation of Trametes versicolor yielded $0.239 \mathrm{~g}$ ethanol from $1 \mathrm{~g}$ non-treated RS (Okamoto et al., 2014). Similarly, Lee et al. (2012) reported an ethanol production of $46.7 \mathrm{~g} / \mathrm{L}$ from $150 \mathrm{~g} / \mathrm{L}$ of liquefied cassava starch by co-immobilization of $S$. cerevisiae with $A$. oryzae after $72 \mathrm{~h}$ incubation while immobilized cells of yeast $S$. diastaticus produced $37.5 \mathrm{~g} / \mathrm{L}$ ethanol corresponding to ethanol yield conversion of 0.311 and $0.25 \mathrm{~g} / \mathrm{g}$ of cassava, respectively. There may be several reasons for low yield of ethanol in our study. The culture could be inefficient and sugar content in the substrate could be low or inoculation conditions were not optimum. As such, there is no consistency in the reports on different studies in organism, pretreatment methods, and inoculation conditions. In the current study, it was not possible to execute elaborate experiments taking into considerations on different variables for the five substrates. However, in our study, untreated CS yielded $0.83 \mathrm{~g} / \mathrm{L}$ ethanol. In recent time, there has been lot of emphasis given on use of CBP for production of bioethanol from treated and untreated agricultural wastes employing filamentous fungi through CBP (Okamoto et al., 2011; Shahin et al., 2012). In our future experiments, ethanol production will be attempted using the six substrates through variations in conditions between fermentation parameters, fungal cultures, and pretreatments.

\section{CONCLUSION}

The six LCB viz. sugarcane BG, CS, FF, PH, RS, and SD contained varied amount of lignin, cellulose, hemicellulose, monosaccharides, disaccharides, and inhibitors of fermentation. SEM, FT-IR, and HPLC analysis could indicate structural and compositional changes brought about by hydrothermal and $\mathrm{NaOH}$ pretreatments of these LCB. Hydrothermal pretreatment was found to be an efficient method to release desirable amounts of fermentable sugars and inhibitors and enhance the enzymatic saccharification. Preliminary screening on four selected substrates (untreated and hydrothermally treated) for bioethanol production through saccharification and fermentative action of MTCC 1755 showed that ethanol production from untreated CS was comparable with that from hydrothermally treated BG. Based on these results, optimization of different process and enzyme loading parameters should be the goal of future research to enhance ethanol yield from this potential substrate.

\section{AUTHOR CONTRIBUTIONS}

NT and GN designed and coordinated the study. GN carried out the experiments. NT, RL, and GN analyzed the results. NT and GN wrote the paper, and NT, RL, SD, and PH reviewed the paper. All authors read and approved the final manuscript.

\section{ACKNOWLEDGMENTS}

This publication has emanated from research conducted with the financial support from UGC [Grant No. F.2-6/2012 (SA-I)] and DBT in the form of Junior Research Fellowship for the PhD program at Institute of Bioresources and Sustainable Development, India. We thank Mr. Saurav Dey (GBP, Guwahati IIT Campus) for assisting with HPLC analysis. 


\section{REFERENCES}

Berlin, A., Gikes, N., Kurabi, A., Bura, R., Tu, M., Kilbum, D., et al. (2005). Weak lignin-binding enzymes. Appl. Biochem. Biotechnol. 121, 163-170. doi:10.1385/ ABAB:121:1-3:0163

Binod, P., Sindhu, R., Singhania, R. R., Vikram, S., Devi, L., Nagalakshmi, S., et al. (2010). Bioethanol production from rice straw: an overview. Bioresour. Technol. 101, 4767-4774. doi:10.1016/j.biortech.2009.10.079

Buranov, A. U., and Mazza, G. (2010). Extraction and characterization of hemicelluloses from flax shives by different methods. Carbohydr. Polym. 9, 17-25. doi:10.1016/j.carbpol.2009.06.014

Chen, L. M., Wilson, R. H., and McCann, M. C. (1997). Investigation of macromolecule orientation in dry and hydrated walls of single onion epidermal cells by FTIR micro spectroscopy. J. Mol. Struct. 408, 257-260. doi:10.1016/S0022-2860(96)09539-7

Chen, W. H., Pen, B. L., Yu, C. T., and Hwang, W. S. (2011). Pretreatment efficiency and structural characterization of rice straw by an integrated process of diluteacid and steam explosion for bioethanol production. Bioresour. Technol. 102, 2916-2924. doi:10.1016/j.biortech.2010.11.052

Colom, X., Carrillo, F., Nogués, F., and Garriga, P. (2003). Structural analysis of photodegraded wood by means of FTIR spectroscopy. Polym. Degrad. Stab. 80, 543-549. doi:10.1016/S0141-3910(03)00051-X

Da Cruz, S. H., Dien, B. S., Nichols, N. N., Saha, B. C., and Cotta, M. A. (2012). Hydrothermal pretreatment of sugarcane bagasse using response surface methodology improves digestibility and ethanol production by SSF. J. Ind. Microbiol. Biotechnol. 39, 439-447. doi:10.1007/s10295-011-1051-3

Donohoe, B. S., Decker, S. R., Tucker, M. P., Himmel, M. E., and Vinzant, T. B. (2008). Visualizing lignin coalescence and migration through maize cell walls following thermochemical pretreatment. Biotechnol. Bioeng. 101, 913-925. doi:10.1002/bit.21959

Eika, W. Q. (2014). "Pretreatment and saccharification of lignocellulosic biomass," in Research Approaches to Sustainable Biomass Systems, eds S. Tojo and T. Hirasawa (San Diego, CA: Academic Press Elsevier Inc), 181-204.

Erdei, B., Barta, Z., Sipos, B., Réczey, K., Galbe, M., and Zaccgi, G. (2010). Ethanol production from mixtures of wheat straw and wheat meal. Biotechnol. Biofuels 3, 16. doi:10.1186/1754-6834-3-16

Gastaldi, G., Capretti, G., Focher, B., and Cosentino, C. (1998). Characterization and properties of cellulose isolated from the Crambe abyssinica hull. Ind. Crops Prod. 8, 205-218. doi:10.1016/S0926-6690(98)00004-1

Goodwin, J. F. (1970). Method for simultaneous direct estimation of glucose and xylose in serum. Clin. Chem. 16, 85-91.

Gunjkar, T. P., Sawant, S. B., and Joshi, J. B. (2001). Shear deactivation of cellulose, exoglucanase and $\beta$-glucosidase in a mechanically agitated reactor. Biotechnol. Prog. 17, 1166-1168. doi:10.1021/bp010114u

Guo, B., Zhang, Y., Yu, G., Lee, W. H., Jin, Y. S., and Morgenroth, E. (2013). Two stage acidic-alkaline hydrothermal pretreatment of lignocellulose for the high recovery of cellulose and hemicellulose sugars. Appl. Biochem. Biotechnol. 169, 1069-1087. doi:10.1007/s12010-012-0038-5

Hossain, S. M., Anantharaman, N., and Das, M. (2012). Bioethanol fermentation from untreated and pretreated bagasse using Fusarium oxysporum. Indian Chem. Eng. 53, 18-32. doi:10.1080/00194506.2011.659540

Kim, T. H., and Lee, Y. Y. (2006). Fractionation of corn stover by hot-water and aqueous ammonia treatment. Bioresour. Technol. 97, 224-232. doi:10.1016/j. biortech.2005.02.040

Kumar, R., Hu, F., Sannigrahi, P., Jung, S., Ragauskas, A. J., and Wyman, C. E. (2013). Carbohydrate derived-pseudo-lignin can retard cellulose biological conversion. Biotechnol. Bioeng. 110, 737-753. doi:10.1002/bit.24744

Kumar, R., Mago, G., Balan, V., and Wyman, C. E. (2009). Physical and chemical characterizations of corn stover and poplar solids resulting from leading pretreatment technologies. Bioresour. Technol. 100, 3948-3962. doi:10.1016/j. biortech.2009.01.075

Kumar, R., and Wyman, C. E. (2009). Access of cellulose to cellulose and lignin for poplar solids produced by leading pretreatment technologies. Biotechnol. Prog. 25, 807-819. doi:10.1002/btpr.153

La Rovere, E. L., Pereira, A. S., and Simões, A. F. (2011). Biofuels and sustainable energy development Brazil. World Dev. 39, 1026-1036. doi:10.1016/j. worlddev.2010.01.004

Larsen, S. U., Bruun, S., and Lindedam, J. (2012). Straw yield and saccharification potential for ethanol in cereal species and wheat cultivars. Biomass Bioenergy 45, 239-250. doi:10.1016/j.biombioe.2012.06.012
Larsson, S., Palmqvist, E., Hahn-Hagerdal, B., Tengborg, C., Stenberg, K., Zacchi, G., et al. (1998). The generation of fermentation inhibitors during dilute acid hydrolysis of softwood. Enzyme Microb. Technol. 3, 151-159.

Laser, M., Schulman, D., Allen, S. G., Lichwa, J., Antal, M. J., and Lynd, L. R. (2002). A comparison of liquid hot water and steam pretreatments of sugar cane bagasse for bioconversion to ethanol. Bioresour. Technol. 81, 33-44. doi:10.1016/S0960-8524(01)00103-1

Lau, M. J., Lau, M. W., Gunawan, C., and Dale, B. E. (2010). Ammonia fiber expansion (AFEX) pretreatment, enzymatic hydrolysis, and fermentation on empty palm fruit bunch fiber (EPFBF) for cellulosic ethanol production. Appl. Biochem. Biotechnol. 162, 1847-1857. doi:10.1007/s12010-010-8962-8

Lee, W. S., Chen, I. C., Chang, C. H., and Yang, S. S. (2012). Bioethanol production from sweet potato by co-immobilization of saccharolytic molds and Saccharomyces cerevisiae. Ren. Energy. 39, 216-222. doi:10.1016/j.renene.2011. 08.024

Li, H., Pu, Y., Kumar, R., Ragauskas, A. J., and Wyman, C. E. (2014). Investigation of lignin deposition on cellulose during hydrothermal pretreatment, its effect on cellulose hydrolysis, and underlying mechanisms. Biotechnol. Bioeng. 111, 485-492. doi:10.1002/bit.25108

Lima, M. A., Gomez, L. D., Steele-King, C. G., Simister, R., Bernardinelli, O. D., Carvalho, M. A., et al. (2014). Evaluating the composition and processing potential of novel sources of Brazilian biomass for sustainable biorenewables production. Biotechnol. Biofuels 7, 10. doi:10.1186/1754-6834-7-10

Liu, L., Sun, J., Cai, C., Wang, S., Pei, H., and Zhang, J. (2009). Corn stover pretreatment by inorganic salts and its effects on hemicellulose and cellulose degradation. Bioresour. Technol. 100, 5865-5871. doi:10.1016/j.biortech. 2009.06.048

Liyakathali, N. A. M. (2014). Ultrasonic Pretreatment of Energy Cane Bagasse for Biofuel Production. Master's Thesis, Anna University, Chennai, India.

Martín, C., Marcet, M., Almazán, O., and Jönsson, L. J. (2007). Adaptation of a recombinant xylose-utilizing Saccharomyces cerevisiae strain to a sugarcane bagasse hydrolysate with high content of fermentation inhibitors. Bioresour. Technol. 98, 1767-1773. doi:10.1016/j.biortech.2006.07.021

Miller, G. L. (1959). Use of dinitrosalicylic acid reagent for determination of reducing sugar. Anal. Chem. 13, 426-428. doi:10.1021/ac60147a030

Mussatto, S. I., Dragone, G., Fernades, M., Milagres, A. M. F., and Roberto, I. C. (2008). The effect of agitation speed, enzyme loading and substrate concentration on enzymatic hydrolysis of cellulose from brewer's spent grain. Cellulose 15, 711-721. doi:10.1007/s10570-008-9215-7

Navarro, A. R. (1994). Effects of furfural on ethanol fermentation by Saccharomyces cerevisiae-mathematical models. Curr. Microb. 2, 87-90. doi:10.1007/ BF01575753

Nlewem, K. C., and Thrash, M. E. Jr. (2010). Comparison of different pretreatment methods based on residual lignin effect on the enzymatic hydrolysis of switchgrass. Bioresour. Technol. 101, 5426-5430. doi:10.1016/j.biortech.2010.02.031

Okamoto, K., Nitta, Y., Maekawa, N., and Yanase, H. (2011). Direct ethanol production from starch, wheat bran and rice straw by the white rot fungus Trametes hirsuta. Enzyme Microbial Technol. 48, 273-277. doi:10.1016/j. enzmictec.2010.12.001

Okamoto, K., Uchii, A., Kanawaku, R., and Yanase, H. (2014). Bioconversion of xylose, hexoses and biomass to ethanol by a new isolate of the white rot basidiomycete Trametes versicolor. Springerplus 3, 121. doi:10.1186/2193-18013-121

Owen, N. L., and Thomas, D. W. (1989). Infrared studies of hard and soft woods. Appl. Spectrosc. 43, 451-455. doi:10.1366/0003702894202760

Palmqvist, E., Hahn-Hägerdal, B., Galbe, M., and Zacchi, G. (1996). The effect of water soluble inhibitors from steam-pretreated willow on enzymatic hydrolysis and ethanol fermentation. Enzyme Microb. Technol. 6, 470-476. doi:10.1016/ S0141-0229(95)00234-0

Pandey, K. K. (1999). A study of chemical structure of soft and hardwood and wood polymers by FTIR spectroscopy. J. Appl. Polym. Sci. 12, 1969-1975. doi:10.1002/(SICI) 1097-4628(19990321)71:12<1969::AID-APP6>3.3.CO;2-4

Pandey, K. K. (2005). Study of the effect of photo-irradiation on the surface chemistry of wood. Polym. Degrad. Stab. 90, 9-20. doi:10.1016/j.polymdegradstab. 2005.02.009

Pandey, K. K., and Pitman, A. J. (2003). FTIR studies of the changes in wood chemistry following decay by brown-rot and white-rot fungi. Int. Biodeterior. Biodegrad. 52, 151-160. doi:10.1016/S0964-8305(03)00052-0 
Pu, Y., Hu, F., Huang, F., Davison, B. H., and Ragauskas, A. J. (2013). Assessing the molecular structure basis for biomass recalcitrance during dilute acid and hydrothermal pretreatments. Biotechnol. Biofuels 6, 15-27. doi:10.1186/ 1754-6834-6-15

Rezende, C. A., de Lima, M. A., Maziero, P., de Azevedo, E. R., Garcia, W., and Polikarpov, I. (2011). Chemical and morphological characterization of sugarcane bagasse submitted to a delignification process for enhanced enzymatic digestibility. Biotechnol. Biofuels 11, 4-54. doi:10.1186/1754-6834-4-54

Rocha, G. J. M., Martín, C., da Silva, V. F., Gomez, E. O., and Goncalves, A. R. (2012). Mass balance of pilot-scale pretreatment of sugarcane bagasse by steam explosion followed by alkaline delignification. Bioresour. Technol. 111, 447-452. doi:10.1016/j.biortech.2012.02.005

Sanchez, B., and Bautista, J. (1988). Effects of furfural and 5-hydroxymethylfurfural on the fermentation of Saccharomyces cerevisiae and biomass production from Candida guilliermondii. Enzyme Microb. Technol. 5, 315-318. doi:10.1016/0141-0229(88)90135-4

Santos, V. T. O., Esteves, P. J., Milagres, A. M. F., and Carvalho, W. (2011). Characterization of commercial cellulases and their use in the saccharification of a sugarcane bagasse sample pretreated with dilute sulphuric acid. J. Ind. Microb. Biotechnol. 38, 1089-1098. doi:10.1007/s10295-010-0888-1

Selig, M. J., Viamajala, S., Decker, S. R., Tucker, M. P., Himmel, M. E., and Vinzant, T. B. (2007). Deposition of lignin droplets produced during dilute acid pretreatment of maize stems retards enzymatic hydrolysis of cellulose. Biotechnol. Prog. 23, 1333-1339. doi:10.1021/bp0702018

Shahin, S. A., Mojibur, K., Brian, F., Ewen, M., and Fiona, M. D. (2012). Exploiting the inter-strain divergence of Fusarium oxysporum for microbial bioprocessing of lignocellulose to bioethanol. AMB Express 2, 16. doi:10.1186/21910855-2-16

Sigurbjornsdottir, M. A., and Orlygsson, J. (2012). Combined hydrogen and ethanol production from sugars and lignocellulosic biomass by Thermoanaero bacterium AK 54, isolated from hot spring. Appl. Energy 97, 785-791. doi:10.1016/j. apenergy.2011.11.035

Singleton, V., and Rossi, J. A. Jr. (1965). Colorimetry of total phenolics with phosphomolybdic-phosphotungstic acid reagents. Am. J. Enol. Vitic. 16, 144-158.

Sun, R. C., and Tomkinson, J. (2002). Characterization of hemicelluloses obtained by classical and ultrasonically assisted extractions from wheat straw. Carbohydr. Polym. 50, 263-271. doi:10.1016/S0144-8617(02)00037-1

Sun, S. L., Sun, S. N., Wen, J. L., Zhang, X. M., Peng, F., and Sun, R. C. (2015). Assessment of integrated process based on hydrothermal and alkaline treatments for enzymatic saccharification of sweet sorghum stems. Bioresour. Technol. 175, 473-479. doi:10.1016/j.biortech.2014.10.111
Sun, S. L., Wen, J. L., Ma, M. G., and Sun, R. C. (2014). Structural elucidation of sorghum lignins from integrated biorefinery process based on hydrothermal and alkaline treatments. J. Agric. Food Chem. 62, 8120-8128. doi:10.1021/ jf501669r

Taherzadeh, M. J., Gustafsson, L., Niklasson, C., and Liden, G. (2000). Physiological effects of 5-hydroxymethylfurfural on Saccharomyces cerevisiae. Appl. Microb. Biotechnol. 6, 701-708. doi:10.1007/s002530000328

Taherzadeh, M. J., and Karimi, K. (2008). Pretreatment of lignocellulosic wastes to improve ethanol and biogas production. A review. Int. J. Mol. Sci. 9, 1621-1651. doi:10.3390/ijms9091621

Tengborg, C., Galbe, M., and Zacchi, G. (2001). Reduced inhibition of enzymatic hydrolysis of steam-pretreated softwood. Enzyme Microb. Technol. 9, 835-844. doi:10.1016/S0141-0229(01)00342-8

Updegraff, D. M. (1969). Semimicro determination of cellulose in biological materials. Anal. Biochem. 32, 420-424. doi:10.1016/S0003-2697(69)80009-6

Xiros, C., and Christakopoulos, P. (2009). Enhanced ethanol production from brewer's spent grain by a Fusarium oxysporum consolidated system. Biotechnolnol. Biofuels 2, 4. doi:10.1186/1754-6834-2-4

Xiros, C., Topakas, E., Katapodis, P., and Christakopoulos, P. (2008). Hydrolysis and fermentation of brewer's spent grain by Neurospora crassa. Bioresour. Technolnol. 99, 5427-5435. doi:10.1016/j.biortech.2007.11.010

Zhang, Y., Fu, X., and Chen, H. (2012). Pretreatment based on two step steam explosion combined with an intermediate separation of fiber cells-optimization of fermentation of corn straw hydrolysates. Bioresour. Technol. 121, 100-104. doi:10.1016/j.biortech.2012.07.006

Zhu, L., O’Dwyer, J. P., Chang, V. S., Granda, C. B., and Holtzapple, M. T. (2008). Structural features affecting biomass enzymatic digestibility. Bioresour. Technol. 99, 3817-3828. doi:10.1016/j.biortech.2007.07.033

Zuber, K., and Dwivedi, A. K. (2013). Fermentation of biomass for production of ethanol: a review. Univ. J. Environ. Res. Technol. 3, 1-13.

Conflict of Interest Statement: The authors declare that the research was conducted in the absence of any commercial or financial relationships that could be construed as a potential conflict of interest.

Copyright (c) 2017 Nongthombam, Labala, Das, Handique and Talukdar. This is an open-access article distributed under the terms of the Creative Commons Attribution License (CC BY). The use, distribution or reproduction in other forums is permitted, provided the original author(s) or licensor are credited and that the original publication in this journal is cited, in accordance with accepted academic practice. No use, distribution or reproduction is permitted which does not comply with these terms. 